\title{
Energy Star: A Competitive Advantage?
}

Thomas S. Joiner, Jr., Colorado College, USA Judith A. Laux, Colorado College, USA

\begin{abstract}
Voluntary government programs such as ENERGY STAR have been created to promote energy efficiency within different organizations and businesses, and this study is dedicated to discovering whether or not businesses that become certified building partners with ENERGY STAR obtain a competitive advantage. Through two different methods of analysis, an observational analysis and a test of means, data on profitability ratios from twenty-five ENERGY STAR partners are examined to determine if partnering with ENERGY STAR results in a competitive advantage.
\end{abstract}

Keywords: ENERGY STAR, competitive advantage, profitability ratio

\section{INTRODUCTION}

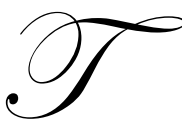

he past twenty years have seen an enormous shift away from the traditional ways of conducting business. Global warming has become a reality, and many industries are attempting to become as eco-friendly as possible [Brandt, 2007, p. 30]. The debate that has arisen from the business trend of eco-friendliness is whether it pays to be "green." Simply pleasing stakeholders is no longer the focal point of environmental responsibility, and many firms are now focusing on ways to prosper financially by doing their part to better the world. Skeptics still exist, however, and many incentive programs have been developed to promote saving the environment.

ENERGY STAR represents one government-run program that encourages "green" business practices. Jointly run by the U.S. Environmental Protection Agency and the U.S. Department of Energy, the program began in 1992 as a voluntary labeling program with the intention of reducing green house gasses through the promotion of energy-efficient products. Initially, the only products labeled were computers and monitors, but in 1995 additional office equipment, heating, and cooling equipment were labeled as well ["ENERGY STAR," 2008, www.energystar.gov]. Today the ENERGY STAR label is prominent on appliances, office equipment, lighting, home electronics, and many other products.

ENERGY STAR has partnered with thousands of organizations ranging from school districts to successful public corporations, and partners have saved over \$14 billion since the designation's inception ["ENERGY STAR," 2008, www.energystar.gov]. Partnering with ENERGY STAR seems to be attractive, but is it really worth it? Does becoming an ENERGY STAR partner generate positive financial performance and result in a competitive advantage? The purpose of this study is to determine whether companies that partner with ENERGY STAR possess a competitive advantage, with the hypothesis that ENERGY STAR partner firms do, in fact, have a competitive advantage. Essentially, examining whether ENERGY STAR firms have a competitive advantage tests two things simultaneously; it examines whether it pays to be energy efficient as well as whether the ENERGY STAR logo creates profitable brand loyalty. Therefore, the next section of this paper presents a summary of the literature related to environmental responsibility and profitability and also a summary of the literature related to the success of ecolabels, such as ENERGY STAR. The review of literature is followed by a presentation of the empirical research conducted on profitability ratios before and after partnering with ENERGY STAR, including two different methodologies - an observational analysis and a test of means. 


\section{A BRIEF REVIEW OF THE LITERATURE}

"The Impact of Environmental Management on Firm Performance" by Robert D. Klassen and Curtis P. McLaughlin hypothesizes that environmental management has the potential to play a pivotal role in the financial performance of a firm [Klassen and McLaughlin, 1996, p. 1199]. The authors use abnormal returns to determine the estimate of the residual for a single day event. By doing so, they determine the influence that environmental announcements have on the share price of a particular company. Share price as a measure of firm performance is deemed appropriate because of a strong willingness by U.S. consumers to pay more for products that save the environment, and according to the Efficient Market Hypothesis, share prices should accurately portray public opinion [Malkiel, 2003, p. 59]. Klassen and McLaughlin use share price to gauge firm performance in this study, an indication that they adhere to Porter's theory that firms align strategy with outside factors [Porter, 1998, p. 557]. The analysis of abnormal returns of share prices reveals that environmental management is linked to the financial performance of a firm.

A study very similar analyzes environmental performance in a slightly different way. "A Resource-Based Perspective on Corporate Environmental Performance and Profitability" [Russo and Fouts, 1997] examines environmental management and firm performance by following the principles of the resource-based view of the firm. The resource-based view of the firm differs from Porter's industrial organization view in that it theorizes that competitive advantage is deeply rooted within the design of a firm's internal strategy as opposed to the way that firms adjust their internal strategy to account for external factors. Rather than using share price to evaluate companies' environmental performances, Russo and Fouts use an environmental rating assigned to different firms designed to provide a measure of the effectiveness of the internal environmental strategies of individual firms. Although not explicitly stated, it can be assumed that the authors use these ratings because they accurately reflect the internal environmental strategy of the firm rather than an external reaction to their strategy. The data are analyzed using a regression analysis with ROA (return on assets) as the dependent variable. While the results of this investigation are less significant than those of the previous study, they still show a modest relationship between higher environmental performances and financial performance.

The studies above provide a good understanding of how environmental business strategies can show an empirical relationship with firm performance. What these studies fail to do, however, is show the different kinds of environmental business strategies that can result in a competitive advantage. Businesses can attempt to achieve an environmental competitive advantage in many different ways. For example, "Competitive Environmental Strategies: When Does it Pay to be Green?" lays out four generic competitive environmental strategies that firms may choose to follow. The four strategies include eco-efficiency, environmental cost leadership, beyondcompliance leadership, and eco-branding [Orsato, 2006, p. 129]. ENERGY STAR designated firms may benefit from any one of these environmental strategies, however, due to the fact that ENERGY STAR is considered an "eco-labeling" program, it is of particular significance to review some literature that pertains to how consumers react to eco-labels such as ENERGY STAR. The subsequent part of this section is dedicated to analyzing survey data formulated to assess the effectiveness of eco-labeling programs, in particular ENERGY STAR, within the U.S.

In addition to the literature that attempts to link environmental responsibility with profitability, a few studies have also attempted to evaluate eco-labeling programs. Abhijit Banerjee and Barry D. Solomon [2003] assess five eco-labeling programs in the U.S. - Green Seal, Scientific Certification Systems, Energy Guide, ENERGY STAR, and Green-e. The evaluation of these programs is based on two criteria: consumer response and manufacturer response. Consumer response to the programs warrants evaluation because of the growing concern of consumers about environmental and energy issues. Manufacturer response is evaluated because a label's effectiveness can be judged by its influence on a manufacturer's actions to meet program criteria. After evaluating all of the five different programs based on survey data and previous studies, the authors find that government programs, specifically the ENERGY STAR program, are more successful than private ones. Programs such as ENERGY STAR excel in their ability to affect the market and capture consumers. Although private label programs are inherently more difficult to evaluate because of limited studies performed on them, this study provides evidence that ENERGY STAR is a superior program to the others, offering support for the hypothesis that the ENERGY STAR designation results in a competitive advantage. 
Members of the Consortium for Energy Efficiency created a survey with the objective of collecting national data on the recognition, understanding, and purchasing influence of the ENERGY STAR label. The study took place during September of 2006 and surveyed a sample of households that are members of an Internet/WebTV panel. The purchasing influence that ENERGY STAR has on consumers was significant, as the survey indicated that $31 \%$ of the households surveyed in 2006 knowingly purchased an ENERGY STAR product; this represented an increase over the 2005 percentage of $24 \%$. These results indicate that the ENERGY STAR label has significant influence on consumers and that it had improved over the two-year period, providing additional insight into whether or not the ENERGY STAR label attracts customers and might result in a competitive advantage.

The evaluations of eco-labeling programs offer sufficient justification for the investigation of the current paper. The fact that the ENERGY STAR designation is the most successful of the five eco-programs evaluated in the first study provides some good rationale for exploring the designation. The second survey that focuses specifically on ENERGY STAR provides relevant information on the influence that the ENERGY STAR label has on consumer purchases. The most important thing to realize from both studies is that the ENERGY STAR label has the potential to generate a competitive advantage by increasing revenues because more people are influenced to buy products that have the ENERGY STAR label. The limitation of these two studies is that they do not explore the question that is at the heart of this study: Do firms that have obtained the ENERGY STAR designation create a competitive advantage because of that ecological association? The following section describes the data and methodology employed to investigate that question.

\section{DATA AND METHODOLOGY}

The ENERGY STAR partner firms included in the analysis are located at ENERGYSTAR.gov. The financial data for the ENERGY STAR partners analyzed in this thesis are found at mergentonline.com and hoovers.com. Information regarding the dates of ENERGY STAR partnership was obtained through e-mail and by contacting the ENERGY STAR hotline over the phone.

As defined by Michael E. Porter, the existence of a competitive advantage is indicated by higher profitability ratios relative to the competition and can be further illustrated by the value of a firm in the marketplace. While some of the previous studies conducted on the relationship between firms' environmental responsibility and financial performance use share prices as a quantitative measure, this study uses profitability ratios to determine relative financial success.

Two different methodologies test whether obtaining the ENERGY STAR designation results in a competitive advantage - an observational analysis and a test of means. The observational analysis compares the profitability ratios of ENERGY STAR partner firms to the average profitability ratios of their industries as well as to their top ten competitors. Within the observational analysis, the profitability ratios are analyzed one year before and one year after the twenty-five firms became ENERGY STAR partners, and ratios from the most current year available are analyzed as well.

A t-test is employed to validate the findings of the observational analysis. The t-test is a test of means to determine if the profitability ratios of ENERGY STAR partner firms vary significantly from the means of the average profitability ratios of their industries and top competitors. The results and analysis are described in the following section.

\section{RESULTS AND ANALYSIS}

The first comparison utilizes industry averages to determine the existence of competitive advantage. The first set of columns in Table 1 displays the results of the observational analysis for the sample firms the year before they partnered with ENERGY STAR. Unfortunately, due to an inability to collect historical data past 1999 on mergentonline.com, the sample size initially was reduced to sixteen. Officemax was also removed from the 


\begin{tabular}{|c|c|c|c|c|c|c|c|c|c|}
\hline \multicolumn{10}{|c|}{$\begin{array}{l}\text { COMPETITIVE ADVANTAGE } \\
\text { Using Industry Averages } \\
(\mathrm{Y}=\mathrm{Yes}, \mathrm{N}=\mathrm{No})\end{array}$} \\
\hline \multirow[t]{2}{*}{ Company (Pre-partner, post partner year) } & \multicolumn{3}{|c|}{ Before Partnering with ENERGY STAR } & \multicolumn{3}{|c|}{ After Partnering with ENERGY STAR } & \multicolumn{3}{|c|}{ Currently } \\
\hline & Profit Margin & $\underline{\text { ROA }}$ & ROE & Profit Margin & $\underline{\text { ROA }}$ & ROE & Profit Margin & ROA & $\underline{\mathrm{ROE}}$ \\
\hline ALLTEL Corp.-2000, 2002 & $\mathrm{Y}$ & $\mathrm{Y}$ & $\mathrm{N}$ & $\mathrm{Y}$ & $\mathrm{Y}$ & $\mathrm{Y}$ & $\mathrm{Y}$ & $\mathrm{Y}$ & $\overline{\mathrm{Y}}$ \\
\hline Bed, Bath and Beyond-2000, 2002 & $\mathrm{Y}$ & $\mathrm{Y}$ & $\mathrm{Y}$ & $\mathrm{Y}$ & $\mathrm{Y}$ & $\mathrm{Y}$ & $\mathrm{Y}$ & $\mathrm{N}$ & $\mathrm{N}$ \\
\hline Blockbuster, Inc.-2000, 2002 & $\mathrm{Y}$ & Y & $\mathrm{N}$ & $\mathrm{N}$ & $\mathrm{Y}$ & $\mathrm{N}$ & $\mathrm{Y}$ & $\mathrm{Y}$ & $\mathrm{Y}$ \\
\hline Cisco Systems, Inc.-1999, 2001 & Y & $\mathrm{Y}$ & $\mathrm{Y}$ & $\mathrm{Y}$ & $\mathrm{Y}$ & $\mathrm{Y}$ & Y & $\mathrm{Y}$ & $\mathrm{Y}$ \\
\hline Disney Co. - 2000, 2002 & $\mathrm{~N}$ & $\mathrm{~N}$ & $\mathrm{~N}$ & $\mathrm{Y}$ & $\mathrm{Y}$ & $\mathrm{Y}$ & $\mathrm{Y}$ & $\mathrm{Y}$ & $\mathrm{N}$ \\
\hline Ford Motor Co. (DE)-2000, 2002 & Y & $\mathrm{N}$ & $\mathrm{Y}$ & $\mathrm{Y}$ & $\mathrm{N}$ & $\mathrm{N}$ & $\mathrm{N}$ & $\mathrm{N}$ & $\mathrm{N}$ \\
\hline Humana Inc. $-2006,2008$ & $\mathrm{Y}$ & $\mathrm{Y}$ & $\mathrm{Y}$ & $\mathrm{Y}$ & $\mathrm{Y}$ & $\mathrm{Y}$ & $\mathrm{Y}$ & $\mathrm{Y}$ & $\mathrm{Y}$ \\
\hline Kraft Foods, Inc. $-2006,2008$ & Y & $\mathrm{Y}$ & $\mathrm{Y}$ & $\mathrm{Y}$ & $\mathrm{Y}$ & $\mathrm{Y}$ & $\mathrm{Y}$ & $\mathrm{Y}$ & $\mathrm{Y}$ \\
\hline Marriott International, Inc. (New) -2000, 2002 & $\mathrm{~N}$ & $\mathrm{Y}$ & $\mathrm{Y}$ & $\mathrm{Y}$ & $\mathrm{Y}$ & $\mathrm{Y}$ & $\mathrm{Y}$ & $\mathrm{N}$ & $\mathrm{N}$ \\
\hline PepsiCo, Inc.-2005, 2007 & $\mathrm{Y}$ & $\mathrm{Y}$ & $\mathrm{Y}$ & $\mathrm{Y}$ & $\mathrm{Y}$ & $\mathrm{Y}$ & $\mathrm{N}$ & $\mathrm{Y}$ & $\mathrm{Y}$ \\
\hline Pfizer-2000, 2002 & $\mathrm{Y}$ & $\mathrm{Y}$ & $\mathrm{Y}$ & $\mathrm{Y}$ & $\mathrm{Y}$ & $\mathrm{Y}$ & $\mathrm{Y}$ & $\mathrm{Y}$ & $\mathrm{N}$ \\
\hline Toyota Motor Corp. (Japan) -2002, 2004 & $\mathrm{Y}$ & $\mathrm{N}$ & $\mathrm{N}$ & $\mathrm{Y}$ & $\mathrm{Y}$ & $\mathrm{Y}$ & $\mathrm{N}$ & $\mathrm{Y}$ & $\mathrm{Y}$ \\
\hline Wal-Mart Stores, Inc. - 2000, 2002 & $\mathrm{~N}$ & $\mathrm{~N}$ & $\mathrm{~N}$ & $\mathrm{Y}$ & $\mathrm{Y}$ & $\mathrm{Y}$ & $\mathrm{Y}$ & $\mathrm{Y}$ & $\mathrm{Y}$ \\
\hline Whole Foods Market Corp.-2005, 2007 & $\mathrm{Y}$ & $\mathrm{Y}$ & $\mathrm{Y}$ & $\mathrm{N}$ & $\mathrm{Y}$ & $\mathrm{Y}$ & $\mathrm{Y}$ & $\mathrm{Y}$ & $\mathrm{N}$ \\
\hline Winn-Dixie Stores, Inc.-2002, 2004 & $\mathrm{~N}$ & $\mathrm{Y}$ & $\mathrm{Y}$ & $\mathrm{N}$ & $\mathrm{N}$ & $\mathrm{N}$ & $\mathrm{Y}$ & $\mathrm{Y}$ & $\mathrm{N}$ \\
\hline \multicolumn{10}{|l|}{ Remaining firms of initial sample (of 25) } \\
\hline Baxter International, Inc. & & & & & & & $\mathrm{N}$ & $\mathrm{Y}$ & $\mathrm{N}$ \\
\hline Boeing Co. (The) & & & & & & & $\mathrm{N}$ & $\mathrm{Y}$ & $\mathrm{Y}$ \\
\hline Dell Inc & & & & & & & $\mathrm{Y}$ & $\mathrm{Y}$ & $\mathrm{Y}$ \\
\hline Home Depot & & & & & & & $\mathrm{N}$ & $\mathrm{Y}$ & $\mathrm{Y}$ \\
\hline Kellogg Co. & & & & & & & $\mathrm{Y}$ & $\mathrm{Y}$ & $\mathrm{Y}$ \\
\hline Officemax (no industry comparison) & & & & & & & & & \\
\hline Saks, Inc. & & & & & & & $\mathrm{Y}$ & $\mathrm{Y}$ & $\mathrm{Y}$ \\
\hline Target Corp & & & & & & & $\mathrm{Y}$ & $\mathrm{Y}$ & $\mathrm{Y}$ \\
\hline $3 \mathrm{M}$ Co (United States) & & & & & & & $\mathrm{N}$ & $\mathrm{Y}$ & $\mathrm{N}$ \\
\hline Tyco Electronics & & & & & & & $\mathrm{Y}$ & $\mathrm{Y}$ & $\mathrm{Y}$ \\
\hline
\end{tabular}


industry before and after portion of the study due to incomplete data on the firm, leaving the sample size at fifteen firms for Tables 1 and 2. Seven of the fifteen firms demonstrate a competitive advantage for all three profitability ratios before partnering with ENERGY STAR. Marriott Intl., Inc. and Disney Co. are the only two firms that demonstrate no competitive advantage in all three profitability ratio categories.

The second column of Table 1 displays the results from the observational analysis one year after partnering with ENERGY STAR. Eleven of the firms examined demonstrate having a competitive advantage the year after partnering with ENERGY STAR. Winn-Dixie Stores, Inc. is the only firm that demonstrates not having a competitive advantage in any of the three ratio categories. Marriott Intl., Inc. and Disney Co. both demonstrate having no competitive advantage before partnering with ENERGY STAR and are among the eleven firms that demonstrate a competitive advantage for all three profitability ratios after the partnership.

Finally, the third set of columns of Table 1 displays the results of the observational analysis for the twentyfive ENERGY STAR partner firms as compared to their respective industries. The majority of the firms in the sample demonstrate that they currently hold a competitive advantage within their industries in at least one of the three profitability ratios. Twelve of the firms in the sample demonstrate having a current competitive advantage in their industries for all three profitability ratios. Ford Motor Co. is the only firm that has no competitive advantage for all three ratios.

Table 2 shows the results of the observational analysis for the sixteen firms, as compared the top ten closest competitors as defined by mergentonline.com. The top competitor portion of the study is a much stricter way to measure ENERGY STAR partner firms against their competition. Therefore, in this section of the study it is less likely that any major differences exist among the profitability ratios of ENERGY STAR partners and their competitors. As the first set of columns of the table indicates, eight of the firms tested demonstrate a pre-partnering competitive advantage for all three profitability ratios, while Humana Inc., Pfizer, and Disney Co. display not having a competitive advantage for all three profitability ratios.

The second set of columns displays the results for the sixteen firms after partnering with ENERGY STAR as compared to their top ten competitors. Nine firms demonstrate having a competitive advantage after partnering with ENERGY STAR in all three profitability ratio categories. Winn-Dixie Stores, Inc. is the only firm that demonstrates not having a competitive advantage for all three profitability ratios.

The third set of columns shows the most recent results of the observational analysis for the twenty-five ENERGY STAR partners as compared their top ten closest competitors. Thirteen of the firms in the sample demonstrate currently maintaining a competitive advantage over the top ten firms in their industry. Ford Motor Co. and Tyco Electronics are the only two firms that demonstrate not having a competitive advantage for all three profitability ratios.

\section{TEST OF MEANS}

To validate the findings, a test of means is employed on the same data used in the observational analysis to determine any statistical significance within the variation of the data on profitability ratios. The null hypothesis is rejected twice - both for ROA of the industry comparison before partnering and for ROA of the top competitors' comparison currently. This is not surprising considering that thirteen of the sixteen firms examined demonstrate having a competitive advantage over their top competitors before partnering with ENERGY STAR and twenty-three of the twenty-five firms obtain a competitive advantage within their respective industries for the ROA measure. Both sections of the observational analysis display statistical evidence upholding the hypothesis that ENERGY STAR partner firms' ROA is above that of their competition. Although the variation in ROA among these firms can be the product of many things, it provides some minor support of the hypothesis that ENERGY STAR partner firms obtain a competitive advantage over the competition. The results were fairly mixed across all of the other observational analyses, so it is also not astounding that none of the other analyses were upheld statistically. 


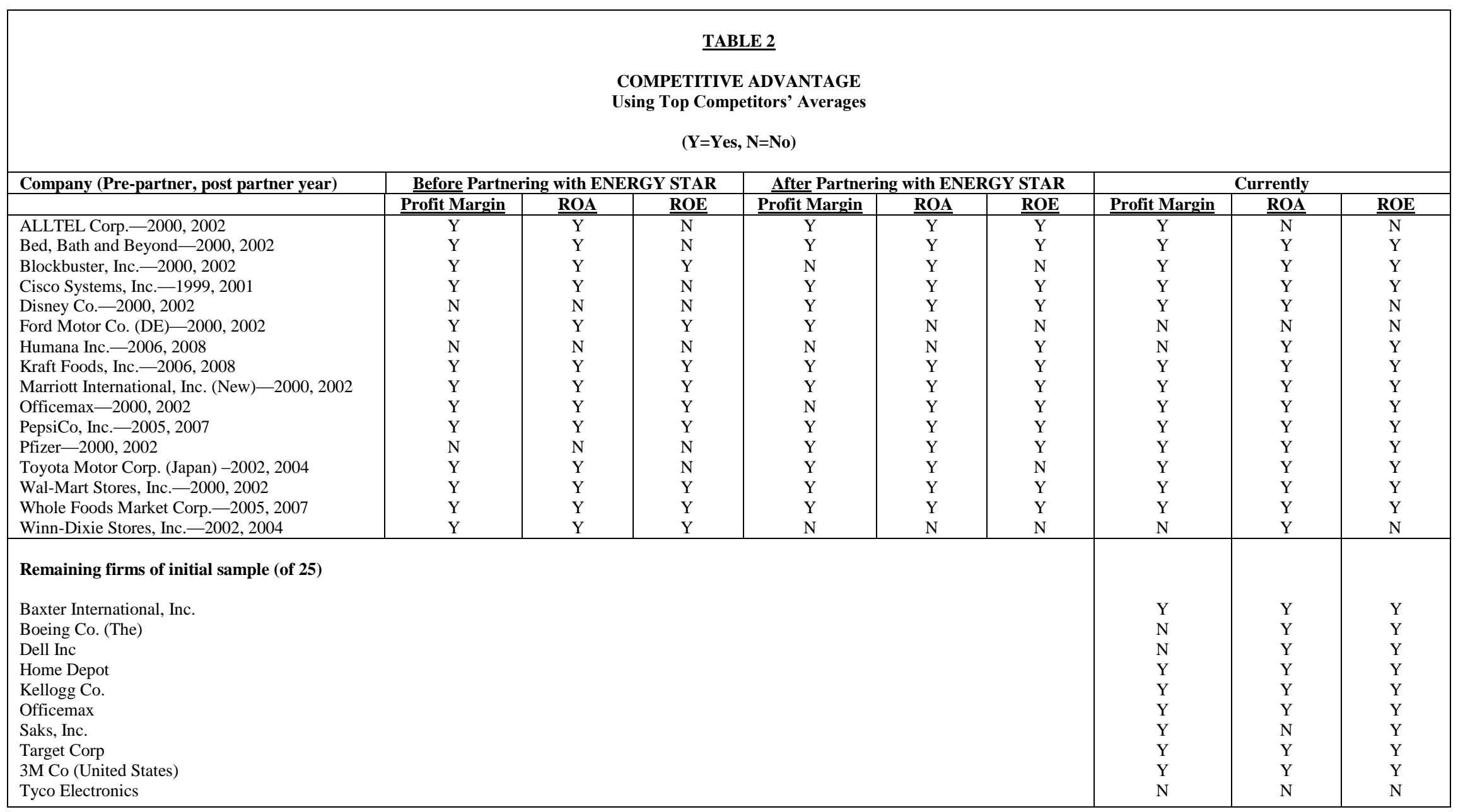




\section{CONCLUSION}

This study presents the hypothesis that ENERGY STAR partner firms have a competitive advantage over other firms in their respective industries. The hypothesis is based on Michael E. Porter's theory of competitive advantage along with other theories pertaining to creating a competitive advantage through environmental business strategy. Investigating whether programs like ENERGY STAR provide a competitive advantage for firms is extremely helpful in determining the most effective methods of how to solve our global environmental issues related to business. An empirical study containing two unconventional methodologies and a typical tool for data analysis revealed that, while there is not enough significant evidence to uphold the hypothesis, enough evidence exists to further examine the topic.

The initial major problem and limitation of the study is that only a small sample of ENERGY STAR firms was analyzed due to the nature of the methodologies; only twenty-five ENERGY STAR partners were analyzed of a possible 2,000. This creates a false representation of the "average" ENERGY STAR firm, which is the question at the heart of this study. A different methodological approach investigating a much larger amount of data, such as a regression analysis, could possibly remedy this shortcoming.

Furthermore, the study contains historical profitability ratios computed by mergentonline.com that may be skewed due to the inclusion of outlier firms in the calculation of industry averages. This problem is a significant one because it compromises part of the observational analysis as well as some of the t-tests. A potential method of correction for the skewed data is to locate or purchase profitability ratios from another financial website.

A third and perhaps the most significant problem with the study is that the top competitor section of the analysis contains some firms that obtain a competitive advantage while those same firms show no competitive advantage within their industry. It seems counterintuitive that a firm has a competitive advantage over their top competitors doesn't demonstrate obtaining one within in their industry. This could result from the fact that mergentonline.com does not clearly define how they choose the top ten closest competitors of a firm. It is possible that mergentonline.com assigns firms' top competitors not by financial performance but by the congruence of the nature of the business that a firm conducts. For example, perhaps Wal-Mart is a top competitor of Target because their activities are so closely related and not because their profits are similar.

The most interesting characteristic about this thesis is that it is the first of its kind. To date no study pertaining to the ENERGY STAR designation is of this type nor examines the same question. Because this thesis is the first of its kind, it has created numerous avenues for further research in the field. A few possible ideas include a comprehensive study examining all ENERGY STAR partner organizations to determine whether being an ENERGY STAR partner benefits some organizations more than others (e.g., businesses vs. schools), a survey study to classify and determine whether ENERGY STAR partner firms fit the mold of a generic or environmental strategy, or a stock market analysis that more thoroughly examines the effects of an ENERGY STAR designation on firm performance in the marketplace (regression analysis). This investigation has triumphed in creating a piece of literature that can be referred to by others studying the topic for years to come.

\section{AUTHOR INFORMATION}

Thomas Joiner is a 2008 economics graduate from Colorado College whose senior thesis provided the basis for this work.

Judith Laux is a Professor of Economics and Business at Colorado College, teaching and researching in the areas of accounting and finance.

\section{REFERENCES}

1. Banerjee, Abhijit and Barry D. Solomon. 2003. "Eco-Labeling for Energy Efficiency and Sustainability: A Meta-Evaluation of US Programs." Energy Policy. Vol. 31, No. 2: 109-123. 
2. $\quad$ Brandt, David. 2007. “A World Gone Green.” Industrial Engineer. Vol. 39, No. 9: 28-33.

3. "Energy Star." 2008. Available from http://www.energystar.gov. On-line site cited 2/20/08.

4. Klassen, Robert D. and Curtis P. McLaughlin. 1996. "The Impact of Environmental Management on Firm Performance." Management Science. Vol. 42, No. 8: 1199-1214.

5. Malkiel, Burton G. 2003. "The Efficient Market Hypothesis and its Critics." The Journal of Economic Perspectives. Vol. 17, No. 1: 59-82.

6. Orsato, Renato J. 2006. "Competitive Environmental Strategies: When Does It Pay to Be Green?" California Management Review. Vol. 48, No. 2: 127-143.

7. Porter, Michael E. 1998. Competitive Advantage: Creating and Sustaining Superior Performance: With a New Introduction. $1^{\text {st }}$ edition. New York: Free Press.

8. Russo, Michael V. and Paul A. Fouts. 1997. "A Resource-Based Perspective on Corporate Environmental Performance and Profitability.” The Academy of Management Journal. Vol. 40, No. 3: 534-559.

9. United States and Consortium for Energy Efficiency. 2007. National Awareness of ENERGY STAR for 2006. Washington, D.C.: U.S. Environmental Protection Agency, Office of Air and Radiation.

\section{$\underline{\text { NOTES }}$}

